\title{
一時的に構成されたカテゴリー表象によって生じる 虚記憶の検討
}

\author{
田中 光 中條 和光 広島大学
}

\begin{abstract}
False memories produced by tentatively organized categorical representations: The Deese-RoedigerMcDermott (DRM) paradigm using lists of ad hoc category exemplars
\end{abstract}

\author{
Hikaru Tanaka and Kazumitsu Chujo (Hiroshima University)
}

\begin{abstract}
The study presented here investigated whether tentatively organized categorical representations resulting from learning ad hoc category lists produced false memories as well as whether learning a list with themes (category labels) increased the prevalence of false memories. A sample of university students $(N=48)$ participated in an experiment using the Deese-Roediger-McDermott paradigm, which presented them with word lists consisting of atypical exemplars of ad hoc categories designed to obscure the themes. The participants studied the lists with or without category labels, and then engaged in a recognition test. The lure items for each recognition list were category exemplars that the participants did not learn. The results indicated that false recognition occurred as a result of learning ad hoc category lists and increased when learning a list with category labels. In addition, participants who noticed a theme reported false recognition more frequently than those who did not, even in the condition where labels were not presented. These findings suggest that noticing themes promotes false recognition regardless of the presence of category labels.
\end{abstract}

Key words: false memory, DRM paradigm, ad hoc category, mental representation, semantic network.

The Japanese Journal of Psychology

2019, Vol. 90, No. 5, pp. 513-519

J-STAGE Advanced published date: November 15, 2019, https://doi.org/10.4992/jjpsy.90.18323

実際に経験していない事象をあたかも経験したかの ように思い出すことは, 虚記憶と呼ばれている (Roediger \& McDermott, 1995)。虚記憶はその根底に ある表象の構造や，それを引き起こす認知構造に関し て重要な情報をもたらす（Soro, Ferreira, Semin, Mata, \& Carneiro, 2017）とされ，近年多くの研究がなされて きた。しかし，これまでに実験室的に観察されてきた 虚記憶は主として意味記憶における既存の安定した連 合によって生じるものである。そこで, 本研究では一 時的に構成されたカテゴリー表象によって生じる虚記

Correspondence concerning this article should be sent to: Hikaru Tanaka, Graduate School of Education, Hiroshima University, Kagamiyama, Higashi-Hiroshima 739-8524, Japan. (E-mail: d163332@hiroshima-u.ac.jp)

本研究の実験は日本心理学会第 78 回大会（2014）にて発表さ れたものである（田中・中條, 2014)。本研究は, その後に発表 された Soro et al. (2017) を踏まえて, 一時的に構成されたカテゴ リー表象における虚記憶の生起に関する研究として報告する。
憶について検討する。

これまでに実験室的な虚記憶研究で多く用いられて きたパラダイムに, いわゆる Deese-RoedigerMcDermott パラダイム (以下, DRM パラダイムとする) がある。DRMパラダイムとは，単語リストを学習さ せた後に想起テストを行い, そこで生じる未学習の項 目に対する再生や再認の䛊りを虚記憶の指標とする手 法である。さらに, 虚記憶が生じやすい学習材料とし て, 特定の単語からの連想語で構成されたリスト（以 下, 連想リストとする)が用いられる。連想リストでは, 意味記憶において学習語とルアー語（学習時には呈示 されない連想元の単語）との間に既存の強い連合があ る。そのために, 学習中に学習語から拡散する活性化 がルアー語に集中し，ルアー語の活性值も上昇する。 想起テストにおいて, 項目の活性值が再認判断の手が かりとされることによって高頻度で虚記憶が生じる。 この虚記憶生起の説明は, 活性化モニタリング理論 (activation-monitoring framework: 以下, AMF とする) 
と呼ばれる（Roediger, Balota, \& Watson, 2001; Roediger, McDermott, \& Robinson, 1998)。

また，実験室的研究では，連想リストばかりでなく 分類学的なカテゴリーの事例リスト（以下，コモンリ ストとする) が用いられることもある（Smith， Gerkens, Pierce, \& Choi, 2002)。例えば,「果物」のカ テゴリーに属する「モモ」や「ブドウ」,「ミカン」と いった事例リストの学習によって「リンゴ」のような 未学習の典型事例に対して虚記憶が生じる。Smith et al.（2002）によると，コモンリストの場合，事例間や 上位概念が互いに連想関係にあるために，学習時に未 学習の事例を含めたカテゴリー全体が活性化される。 想起時には, その項目が学習したカテゴリーの事例か どうかが再認判断の拠り所とされ，未学習の事例に対 し虚記憶が生じるとされる。

以上のように，これまで実験室的に検討されてきた 虚記憶は, 学習語間や学習語とルアー語との間に予め 存在する，意味記憶における安定した連合によって説 明されるものであった。これに対し，既存の安定した 連合がない場合であっても，一時的にカテゴリー表象 が形成されるならば虚記憶が生起することが報告され た（Soro et al.（2017）の実験 1）。Soro et al.（2017） では, 安定した連合によって構成された知識構造とし て長期記憶内には存在しておらず，一時的に自発的に 構築される表象として，アドホックカテゴリー （Barsalou, 1983）を用いた実験が行われた。アドホッ クカテゴリーとは,「水」や「ライト」,「寝袋」,「虫 よけスプレー」等を事例とする「キャンプに持ってい くもの」のようなカテゴリーである。実験では, DRMパラダイムを用い, 事例のリスト (以下, アドホッ クリストとする）の学習によって未学習の事例に対す る虚記憶が生じることを明らかにした。

Soro et al.（2017）は, アドホックリストにおける 虚記憶の生起を, 従来, 連想リストにおける虚記憶生 起の説明に適用されてきたAMFと fuzzy-trace theory (以下, FTT とする)（Brainerd \& Reyna, 2002）とによっ て説明している。上述したように, AMF は虚記憶の 生起を学習中にルアー語の活性值が上昇することに よって説明するものである。一方, FTT は情報の取得, 処理, 検索の各処理段階において, ヴァーベイティム （verbatim：語の表層形態の情報）とジスト（gist：意

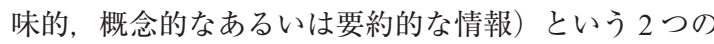
形式の表象に関して処理が生じるとする理論である。 FTTでは，学習中に学習語のジストが集約されること によってリスト全体のジストが抽出され, それがテス 卜時に手がかりとなり虚記憶が生じるとされる。した がって, 両理論ともに, 連想リストに対して, 学習中 に意味記憶における連合を介して連想元の単語（FTT においてはリスト全体のジストに相当）が活性化する ことによって虚記憶が生じると説明する。 Soro et al.（2017）は，コモンリストにおいても事例間に強い 既存の連合があるために，連想リストと同様の過程に よって虚記憶が生じるとしている。その上で, 既存の 連合がなく，一時的な連合によって形成される表象で あっても, すなわちアドホックカテゴリーであっても 同様に虚記憶が生じると予測した。

しかし, AMF やFTT のみではアドホックカテゴリー の未学習事例の虚記憶を十分に説明しているとは言い 難い。AMFやFTT は連想リストの連想元の単語（ジ スト）に対する虚記憶生起の説明に適用されてきたも のであり，それらのみでは未学習事例に対して虚記憶 が生じることを十分に説明できないと考えられるから である。

この点に関連して, Smith et al. (2002) は, コモン リストにおける虚記憶生起について異なる説明を行っ ている。Smith et al.（2002）では，連想リストの虚記 憶が AMF で説明されるのに対し，コモンリストの虚 記憶は, テスト時に呈示される未学習語が学習語の属 するカテゴリーの事例であることで生じる再認判断時 のエラーによるとされる。Gallo (2006) は, Smith et al.（2002）の議論を援用し，コモンリストにおける虚 記憶生起について, 従来のFTTによる説明と再認判 断時のエラーとの関係を以下のように説明している。 すなわち, リスト学習時に, FTTで説明される過程に よって学習語からリスト全体の主題（ジスト）が抽出 される。想起時には, その主題が手がかりとなり未学 習事例に対する虚記憶が生起するという説明である。 この説明は主題一致性説（thematic consistency）と呼 ばれる。

また, Soro et al. (2017) では, アドホックリスト による虚記憶の生起メカニズムを検討するために，リ ストの項目が特定のカテゴリーの事例であることへの 気づきやすさ (identifiability) によって虚記憶の生起 が影響を受けるかどうかも調べられた。コモンリスト では, リストの学習によってリストのテーマであるカ テゴリーラベルが, 自動的に活性化する可能性が高い のに対し，アドホックカテゴリーは, Barsalou (1983) の定義に依拠すれば，テーマへの気づきを伴って自発 的にその表象が構築されるものである。 Soro et al. （2017）は, 虚記憶が生起するかどうかはリストのテー マの活性化に依存していると予測した。そして, カテ ゴリーラベルを外的に呈示することがテーマへの気づ きを促進するとして, 学習時にラベルの呈示の有無を 操作し, 虚記憶生起を比較した。しかし, 結果は予測 に反し，ラベル呈示の有無による差は生じなかった。 そこで Soro et al.（2017）では，実験 1 において，追 加の条件として学習時にラベルは呈示せず, 記銘教示 に代えて学習リストのテーマを回答させる偶発学習群 を設け，ラベルと回答の一致率と虚記憶生起率との相 関を求めた。その結果, 一致率の高い参加者ほど偶発 
記憶による虚記憶の生起頻度が高く $(r(18)=.54, p=$ .01)，この結果に基づいて予測が支持されたとした。

Soro et al.（2017）は, カテゴリー表象が一時的に 構築されることによっても虚記憶が生じることを示し た点で虚記憶研究に新たな知見を加えるものである。 しかし，その一方で，リストのテーマに対する気づき が虚記憶生起に及ぼす影響について，ラベル呈示の有 無を独立変数とした検証はできていない。後者は，ア ドホックカテゴリーの定義自体にも関わり，ラベルの 呈示によって虚記憶が多く生じるとする当初の予測の 検証は重要であろう。そこで, 本研究では, Soro et al.（2017）の手続きの問題点を改善し，虚記憶生起に 関する結果の再現性に加えて, 学習時のラベル呈示の 影響について検証する。

ラベル呈示に関する当初の予測が支持されなかった 理由として, Soro et al.（2017）では生起頻度の高い 事例によってリストが構成されていたことが考えられ る。これにより, 事例の典型性が高く, カテゴリーラ ベルとの間に既存の強い連想関係があった可能性が考 えられる。そのために，連想リストに対する AMFと FTT の双方の説明と同様に, リスト学習中に学習語か らボトムアップ的にリスト全体のジストに相当するカ テゴリーラベルが活性化されてしまい, ラベル呈示の 有無の操作が無効となった可能性がある。そこで, 本 研究では, コモンとアドホックの両リスト条件におい て, カテゴリーラベルからの生起頻度が比較的低い事 例を用いる。これにより，学習中に学習語からの活性 化拡散が生じにくい事態を設定して虚記憶の生起，及 びカテゴリーラベル呈示の有無が虚記憶の生起に及ぼ す影響を比較検討する。

本研究においては, Soro et al. (2017) と同じく, アドホックリストの学習による虚記憶はテーマを介し たカテゴリー表象全体の活性化に依存して生起すると 仮定する。したがって, コモンリストと同様にアドホッ クリストであっても虚記憶は生起すると予測する。ま た，カテゴリーラベルの外的な呈示によってリスト テーマの気づきが促され，虚記憶の生起率が高まると 予測する。

また, Soro et al.（2017）では, リスト学習によっ て新規に強固な連合が生じている場合には想起意識を 伴う remember判断が生じるとし, 再認テスト時に remember / know / guess 判断 (Dewhurst \& Anderson, 1999）を行わせている。ルアー語が学習時に強く活性 化された場合にはソース情報に関するモニタリングエ ラーが生じる (Payne, Elie, Blackwell, \& Neuschatz, 1996）と報告されており， remember 判断はそのよう なモニタリングエラーに関わる指標であったと考えら れる。そこで, 本研究でもソースモニタリングを反映 する指標を測定する。本研究では, Soro et al. (2017) の方法に代えて再認判断時の確信度評定を求める。矢
野・伊東（2004）は, ソース情報の想起意識がある場 合に確信度が高くなることを報告している。本研究で は，両リストともに項目からラベルへの活性化の集中 は弱く，ラベルを介した未学習事例への活性化拡散も また弱い。そのため，学習中にルアー語とソース情報 の連合は生じにくいと考えられる。したがって, ルアー 語の old 反応時にソース情報の想起意識は生じにく く, 両リストにおいて学習語よりもルアー語の old 反 応の確信度は低くなると予測される。またリスト間で は確信度に差が生じないか, アドホックリストの方が コモンリストより低くなると予測される。

\section{方 法}

Soro et al.（2017）では 10 単語で構成された学習リ ストを使用し, カテゴリーの種類とラベルの有無がと もに参加者間で操作された。本研究では Smith et al.（2002）を参考としてカテゴリーの種類は参加者内 で操作し，ラベル呈示の有無のみを参加者間要因とす る実験を行った。

実験参加者 参加者は, 日本語を母語とする大学生, 大学院生 48 名（男性 22 名, 女性 26 名）であった。

実験計画 学習リストの種類（コモンリスト，アド ホックリスト） ×学習中のカテゴリーラベル呈示の有 無 (ラベル有群, ラベル無群) の 2 要因混合計画であっ た。ラベル有群，ラベル無群ともにそれぞれ 24 名が 参加した。

材料 実験参加者とは異なる大学生 126 名を対象と して，梅本（1969）の連想基準表の作成方法と同様の 方法で, 「次の言葉から思いつく単語を思いつくだけ 記入してください」と教示し, カテゴリー事例を収集 する予備調査を行った。参加者の半数は「乗り物」,「動 物」,「デパートで買えるもの」,「海外旅行に持ってい くもの」, 残り半数は「果物」,「スポーツ」, 「贈り物 にできるもの」,「キャンプに持っていくもの」をカテ ゴリーラベルとして呈示し，それから思いつく単語を 10 語まで調査用紙に記入を求めた。記入された単語 から, 生起頻度が中程度の名詞を選択し，コモンリス ト,アドホックリストともに学習 10 語, ルアー 3 語 からなるそれぞれ4リストを作成した（リストの例を 付録に示した)。項目の生起頻度は, 最大で 63 人中で 62 回であり, 選出した項目の生起頻度の範囲は, 24 一3 回であった。採用した項目の平均生起頻度はコモ ンリスト $10.81(S D=5.85)$, アドホックリスト $10.17(S D$ =4.12）であり，2つのリスト間に有意な差はなかっ た $(t(102)=.63, p=.53, d=.13)$ 。

課題の構成 コモンリスト（「乗り物」，「動物」）の 2 リスト, アドホックリスト（「デパートで買えるも の」,「海外旅行に持っていくもの」）の 2 リストを学 習リストとして用い, 残りの 4 リストは再認テストに おけるディストラクターとした。学習語はリスト単位 
で呈示し，リストの呈示順は異なる種類のカテゴリー が交互に来るように 8 通りを作成し，カウンターバラ ンスした。リスト内の項目の呈示順は参加者ごとにラ ンダムに設定した。教示や項目のディスプレー （FlexScan L350）上での呈示及び反応の取得は, Cedrus 社製 SuperLab ver. 4.5 を用いた。再認リストは, 学習 3 語, 学習統制 3 語（同種類のカテゴリーの未学 習リストからリストの生起頻度順で同順位程度にある 語), ルアー 3 語, ルアー統制 3 語（未学習リストの ルアー語）の計 12 項目で構成され，各学習リストに 応じて 4 通りを作成した。Soro et al. (2017) の再認 テストでは再認リストの項目がランダム順で呈示され たが, 本研究では再認りストを学習リストの呈示順で リスト単位で呈示し，リスト内の項目の呈示順序をラ ンダムとした。

手続き 参加者にはモニターに呈示される語を覚え るよう教示した。ラベル有群では「第 Xブロック」 とカテゴリーラベル（例えば,「乗り物」）が2秒間呈 示され，ラベル無群では「第Xブロック」とのみ呈 示された。その後, 画面中央に学習語が 1 語ずつ, そ れぞれ 1.5 秒呈示された。参加者はコモン，アドホッ ク各 2 リス卜を学習した後, 3 分間の計算課題, 再認 テストを行った。参加者は, old 判断, new 判断をそ れぞれ Yes キー, No キーで回答した。参加者がどち らかのキーを押すと, その判断について「1：全く確 信がない」一「5：非常に確信がある」の 5 段階で評 定する尺度が呈示され，あてはまる数字のキーを押す ことによって確信度判断を行った。確信度判断を行う と, 次の単語が呈示された。再認テスト後, ラベル無 群には,「リストの項目間に共通して連想されること があると感じたかどうか」と「各リストのテーマは何 か」の内省報告を求めた。

\section{結果}

始めに，材料作成方法の変更によってリストのテー マの気づきやすさが低くなっているかどうかの操作確 認を行った。第 1 著者を含む 2 名の評定者で, アドホッ クリスト条件のラベル呈示無群の内省報告とリスト作 成時のラベルとの一致率を求めた。正確に一致した参 加者は無く, Soro et al.（2017）と同様に基準を緩めた 一致率は, Soro et al. (2017) では.47 $(S D=.27)$ であっ たのに対し本研究では.19 $(S D=.02)$ であった。した がって，テーマへの気づきに関する材料作成方法の変 更は有効であったと言えるだろう。また，ラベル呈示 の有無の条件操作の確認として, 内省報告によってラ ベル無群におけるテーマへの気づきの有無を検討し た。アドホックリストでは, 少なくともどちらか一方 のリストに関連性があると回答した人数は 24 人中 11 人であった。一方，コモンリストでは 24 人中 23 人で あった。したがって，アドホックリストでは，ラベル
呈示の有無によって学習リスト構成に対する気づきを ある程度操作できていたと考えられる。

以下の分析では, 虚再認について, ラベル呈示の有 無の群間比較を行うとともに, 内省報告に基づいてア ドホックカテゴリーのラベル無群を関連性の認識有 (11 人) と無 $(13$ 人) に群分けした 3 群間の比較も行っ た。

虚再認 山田・鍋田・岡 - 中條（2009）に従い, ル アー語の old 反応率からルアー統制項目の old 反応率 を減じて各条件の修正虚再認率を算出した (Figure 1)。 学習リストの種類 $\times$ ラベルの有無の 2 要因分散分析を 行ったところ, 学習リストの主効果は見られなかった ものの $\left(F(1,46)=.69, p=.41, M S e=.05, \eta_{\mathrm{p}}{ }^{2}=.01\right)$, ラベルの有無の主効果が有意傾向 $(F(1,46)=3.95, p$ $\left.=.05, M S e=.06, \eta_{\mathrm{p}}{ }^{2}=.08\right)$, 交互作用が有意 $(F(1,46)$ $\left.=7.81, p<.01, M S e=.05, \eta_{\mathrm{p}}{ }^{2}=.15\right)$ となった。単純主 効果の検定では，アドホックリストに扔いて，ラベル 有群のほうがラベル無群よりも有意に高く $(F(1,46)$ $\left.=9.46, p<.01, M S e=.07, \eta_{\mathrm{p}}{ }^{2}=.17\right)$, ラベル無群におい てコモンリストのほうがアドホックリストよりも有意 に高かった。 $\left(F(1,23)=5.31, p=.03, M S e=.06, \eta_{\mathrm{p}}{ }^{2}=\right.$ .19)。

次に,アドホックリスト条件で, ラベル有群 (24人), ラベル無 - 関連性認識有群 (11 人), ラベル無 - 関連 性認識無群（13人）の 3 群を比較した（Figure 2)。1 要因分散分析の結果, 主効果が有意 $(F(2,45)=8.24$, $\left.p<.01, M S e=.06, \eta_{\mathrm{p}}{ }^{2}=.27\right)$ となった。多重比較 (Holm 法, 5\%水準) では, ラベル有群とラベル無一関連性 認識有群との間に有意差は無く $(p=.29, d=.38)$, ラ ベル無－関連性認識無群が, ラベル有群, ラベル無 -

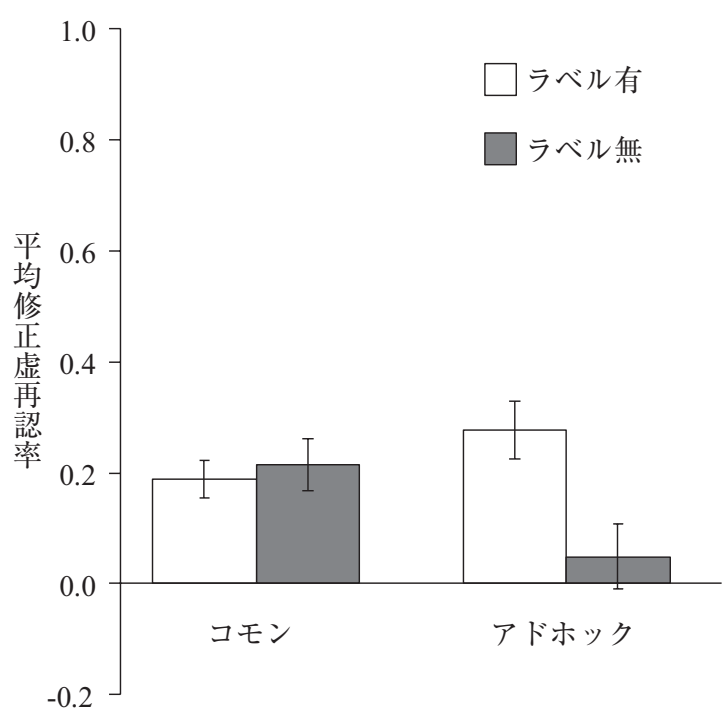

Figure 1. コモンリストとアドホックリストの平均修正虚 再認率 (エラーバーは平均值の標準誤差)。 
関連性認識有群より有意に低かった $(p<.01, d=1.36$, $p=.02, d=.98)$ 。

正再認 山田他（2009）に従い, 学習語の old 反応 率から学習統制項目の old 反応率を減じて修正再認率 を算出した $($ Table 1)。学習リストの種類 $\times$ ラベルの 有無の 2 要因分散分析を行ったところ，ラベルの有無 の主効果は有意ではなかったものの $(F(1,46)=.47, p$ $\left.=.50, M S e=.06, \eta_{\mathrm{p}}{ }^{2}=.01\right)$, 学習リス卜の種類の主効 果 $\left(F(1,46)=14.66, p<.01, M S e=.03, \eta_{\mathrm{p}}{ }^{2}=.24\right)$ と交 互作用 $\left(F(1,46)=6.19, p=.02, M S e=.03, \eta_{\mathrm{p}}{ }^{2}=.12\right)$ が有意となった。単純主効果の検定ではコモンリスト でラベルの効果が有意であった $(F(1,46)=5.18, p=$ $\left..03, M S e=.04, \eta_{\mathrm{p}}^{2}=.10\right)$ 。

確信度 old 反応の確信度の平均評定値を算出した。 このとき, 学習リストの種類 $\times$ ラベルの有無 $\times$ 項目の 種類 (学習語, ルアー語) のいずれかで old 反応がな かった参加者は分析から除外し, ラベル有条件 17 名, ラベル無条件 11 名が分析対象となった。確信度の平 均評定值を Table 2 に示した。3 要因分散分析では項 目の種類の主効果のみが有意であり, 虚再認時に比べ 正再認時の方が高くなった $(F(1,26)=46.72, p<.01$, $\left.M S e=.54, \eta_{\mathrm{p}}{ }^{2}=.64\right)$ 。

\section{考察}

本研究では, アドホックリストにおいても虚記憶が 生起し, またラベルを呈示することで虚記憶の生起率 が高まるとした予測が支持された。後者の結果は, Soro et al.（2017）に扔いて十分に検証されなかった アドホックリストでの虚記憶に対するラベル呈示の効

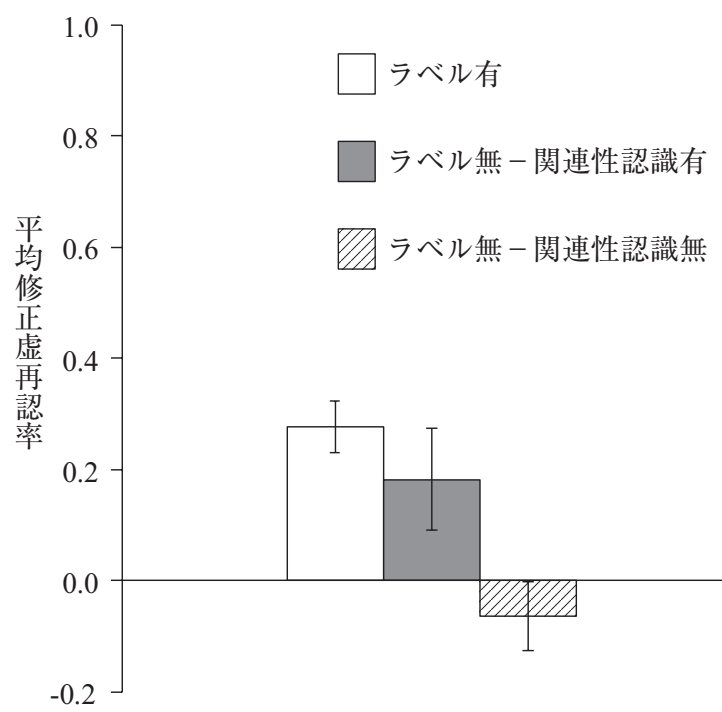

Figure 2. アドホックリストにおける学習語間の関連性へ の気づきと虚再認生起の関係（エラーバーは平均值の標準 誤差)。
Table 1

コモンリストとアドホックリストの平均修正再認率

\begin{tabular}{lcc}
\hline & コモン & アドホック \\
\hline ラベル有 & $.74(.23)$ & $.69(.26)$ \\
ラベル無 & $.87(.14)$ & $.64(.22)$ \\
\hline
\end{tabular}

注）括弧内は標準偏差。

Table 2

old 反応における確信度の平均評定值

\begin{tabular}{lcccc}
\hline & \multicolumn{2}{c}{ コモン } & \multicolumn{2}{c}{ アドホック } \\
\hline ラベル呈示 & 有 & 無 & 有 & 無 \\
\hline 学習語 & $4.18(.66)$ & $4.11(.76)$ & $4.01(.75)$ & $3.81(.80)$ \\
ルアー語 & $3.37(1.16)$ & $2.85(.70)$ & $3.07(.76)$ & $2.94(.84)$ \\
\hline
\end{tabular}

注) 括弧内は標準偏差。

果を実証するものである。

本研究と Soro et al. (2017) の手続きの主たる違い はリスト作成方法であった。カテゴリーラベルとの連 想価の高い事例を用いた Soro et al. (2017) に対し, 本研究では連想価が比較的低い事例でリス卜を構成 し, 学習中に学習語からカテゴリーラベルへの活性化 拡散が生じにくい事態を設定した。そのために, 学習 中にリストのテーマに対する気づきが生じにくかった ことが, ラベルの呈示の有無の効果を生じさせたもの と考えられる。

さらに, ラベル無群において, 関連性認識の有無に よって虚再認率に差があり, 認識有群の虚再認率は認 識無群よりも有意に高く，ラベル有群と有意差がない という結果であった。この結果は, ラベル呈示の有無 に関わりなく虚記憶が生起した Soro et al. (2017) の 結果を再現する一方で，ラベル無群においては虚記憶 の生起が項目間の関連性の認識の有無に依存していた ことを示している。これは, 虚記憶生起にリストのテー マへの気づきが重要な役割を果たしていることを示唆 する知見である。

正再認率と確信度からは，アドホックリストの学習 によって虚記憶が生じるメカニズムが示唆される。ア ドホックリストの虚再認はラベルが呈示された時に多 く生じていたのに対し, 同リスト内学習語の正再認率 にラベル呈示の有無による差は見られなかった。また， 虚再認時の確信度は正再認時よりも低かった。これら の結果からは, 学習時に未学習事例が強く活性化され, そのことが手がかりとなり虚記憶が生じるという AMF は適用できないと考えられる。むしろ，ラベル 呈示によってカテゴリー表象の形成が促され，再認時 に特定のアドホックカテゴリーの事例であることに依 拠した再認判断が行われたことによって虚記憶が生じ ていたことが示唆される。

以上から，アドホックリストにおける虚記憶の生起 
のメカニズムとして, 従来コモンリストの説明とされ てきた主題一致性説を適用できることが示唆される。 アドホックリストの学習による虚記憶生起には, 主題 一致性説に扔ける2段階の過程が関与していると考え られる。第 1 段階は, FTT で説明されるように, アド ホックリストの学習時に学習語のジスト処理によって リスト全体のジストが集約されてカテゴリー表象が形 成される段階である。この時, 外的にカテゴリーラベ ルが呈示されると表象の形成が促される。次に，第 2 段階として, 想起テストにおいてテーマを手がかりと することによる判断エラーによって虚記憶が生じる, という2 段階である。

最後に, 本研究の知見と Soro et al. (2017) の知見 の統合について述べる。上述した2段階の説明からは, Soro et al. (2017) は, 第1段階として, 学習語の処 理によってリスト全体のジストが自動的に活性化し, それを介して未学習事例に活性化が及ぶことによって カテゴリー表象が形成される場合を観察したものと考 えられる。それに対し, 本研究は, 第 1 段階として, 学習語からの活性化拡散に加えて, カテゴリーラベル の気づきに基づく意図的な検索によってカテゴリー表 象の形成が促される場合を観察していたものと考えら れる。したがって, 雨研究の知見は相補的なものと考 えることが妥当である。すなわち, Soro et al. (2017) の事態をボトムアップ的過程が優位な事態とすれば, 本研究はトップダウン的過程優位の事態を観察したも のであったと言えるだろう。

なお，本研究では，ラベル呈示の有無によって学習 中のラベルへの気づきを外的に操作した。しかし， ラ ベル呈示無群の気づきがどの段階で生じたかについて は統制できていない。この点には留意する必要がある だろう。

\section{利益相反}

本研究では, 開示すべき利益相反関連事項はない。

\section{引用文献}

Barsalou, L. W. (1983). Ad hoc categories. Memory \& Cognition, 11, 211-227.

Brainerd, C. J., \& Reyna, V. F. (2002). Fuzzy-trace theory and false memory. Current Directions in Psychological Science, 11, 164-169.
Dewhurst, S. A., \& Anderson, S. J. (1999). Effects of exact and category repetition in true and false recognition memory. Memory \& Cognition, 27, 665-673.

Gallo, D. A. (2006). Associative illusions of memory: False memory research in DRM and related tasks. New York: Psychology Press.

Payne, D. G., Elie, C. J., Blackwell, J. M., \& Neuschatz, J. S. (1996). Memory illusions: Recalling, recognizing, and recollecting events that never occurred. Journal of Memory and Language, 35, 261-285.

Roediger, H. L., III, Balota, D. A., \& Watson, J. M. (2001). Spreading activation and the arousal of false memories. In H. L. Roediger, III, J. S. Nairne, I. Neath, \& A. M. Surprenant (Eds.), The nature of remembering: Essays in honor of Robert G. Crowder (pp. 95-115). Washington, DC: American Psychological Association Press.

Roediger, H. L., III, \& McDermott, K. B. (1995). Creating false memories: Remembering words not presented in lists. Journal of Experimental Psychology: Learning, Memory, and Cognition, 21, 803-814.

Roediger, H. L., III, McDermott, K. B., \& Robinson, K. J. (1998). The role of associative processes in creating false memories. In M. A. Conway, S. E. Gathercole, \& C. Cornoldi (Eds.), Theories of memory II (pp. 187245). Hove, UK: Psychology Press.

Smith, S. M., Gerkens, D. R., Pierce, B. H., \& Choi, H. (2002). The roles of associative responses at study and semantically guided recollection at test in false memory: The Kirkpatrick and Deese hypotheses. Journal of Memory and Language, 47, 436-447.

Soro, J. C., Ferreira, M. B., Semin, G. R., Mata, A., \& Carneiro, P. (2017). Ad hoc categories and false memories: Memory illusions for categories created on-thespot. Journal of Experimental Psychology: Learning, Memory, and Cognition, 43, 1779-1792.

田中光・中條和光 (2014). 虚記憶の生起を指標とし たアドホックカテゴリーの心内表象の検討 日本 心理学会第 78 回大会論文集, 842 .

梅本 堯夫 (1969). 連想基準表一大学生 1000 人の 自由連想による——東京大学出版会

山田恭子・鍋田 智広・岡かおり・中條和光 (2009). 虚再認の生起に及ぼす環境的文脈の効果 心理学 研究, 80, 90-97.

矢野 円郁・伊東 裕司 (2004)。再認記憶の確信度評定 に及ほす親近性と意識的想起の影響 心理学研 究, 75, 324-330.

— 2018.12.21 受稿, 2019.7.6 受理— 
付 録

実験で使用したコモンリストとアドホックリストの例及び各事例の生成率

\begin{tabular}{|c|c|c|c|c|c|c|c|c|}
\hline \multirow{3}{*}{$\begin{array}{l} \\
\text { カテゴリー } \\
\text { ラベル }\end{array}$} & \multicolumn{4}{|c|}{ コモンカテゴリー } & \multicolumn{4}{|c|}{ アドホックカテゴリー } \\
\hline & \multicolumn{2}{|l|}{ 学習リスト } & \multicolumn{2}{|l|}{ 未学習リスト } & \multicolumn{2}{|l|}{ 学習リスト } & \multicolumn{2}{|l|}{ 未学習リスト } \\
\hline & 乗り物 & \multicolumn{2}{|r|}{ スポーツ } & & \multicolumn{2}{|l|}{$\begin{array}{c}\text { 海外旅行に } \\
\text { 持っていくもの }\end{array}$} & \multicolumn{2}{|l|}{$\begin{array}{c}\text { キャンプに } \\
\text { 持っていくもの }\end{array}$} \\
\hline \multirow{27}{*}{$\begin{array}{l}\text { カテゴリー } \\
\text { 事例 }\end{array}$} & 自転車 & .97 & 野球 & .97 & パスポート & .79 & テント & .86 \\
\hline & 自動車 & .87 & サッカー & .92 & お金 & .67 & 食糧 & .56 \\
\hline & 飛行機 & .83 & バスケ & .81 & 服 & .54 & 寝袋 & .46 \\
\hline & 電車 & .81 & バレー & .78 & 携帯電話 & .48 & 虫よけスプレー & .43 \\
\hline & バス & .59 & テニス & .75 & カメラ & .46 & BBQ セット & .33 \\
\hline & 船 & .59 & 水泳 & .70 & ガイドブック & .30 & 懐中電灯 a & .30 \\
\hline & バイク & .51 & バドミントン & .44 & 財布 ${ }^{a}$ & .29 & タオル & .29 \\
\hline & 新幹線 & .46 & ラグビー b & .38 & キャリーバックb & .24 & ランプb & .25 \\
\hline & タクシー a & .29 & 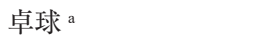 & .35 & 地図 a & .21 & 水 ${ }^{a}$ & .22 \\
\hline & ヘリb & .27 & 陸上 ${ }^{\mathrm{a}}$ & .32 & 時計 & .19 & ライター a & .21 \\
\hline & 原動付き自転車 a & .22 & ハンドボールa & .30 & 歯ブラシ b & .17 & 帽子 & .17 \\
\hline & トラック a & .21 & 剣道 ${ }^{a}$ & .29 & タオル & .17 & ナイフ a & .16 \\
\hline & 一輪車 a & .16 & 柔道 b & .22 & 辞書 a & .17 & リュック a & .14 \\
\hline & モノレール b & .14 & アメフトa & .21 & 着替え a & .16 & 着火マン b & .14 \\
\hline & 三輪車 ${ }^{a}$ & .13 & ラクロス a & .13 & カバン & .16 & 軍手 a & .14 \\
\hline & ジェットコースターa & .13 & 相撲 a & .11 & スマートホンa & .16 & 服 ${ }^{\mathrm{a}}$ & .13 \\
\hline & ボート a & .11 & マラソンa & .11 & 化粧品 ${ }^{a}$ & .16 & 飲み物 & .13 \\
\hline & パトカー a & .10 & フットサル a & .10 & 水 & .14 & 飯盒 & .13 \\
\hline & ヨット a & .08 & 体操 & .10 & 薬 & .14 & 着替え & .13 \\
\hline & 消防車 ${ }^{a}$ & .08 & ゴルフ & .08 & 下着 & .13 & 日焼け止め & .13 \\
\hline & フェリーb & .08 & スキー a & .06 & 充電器 ${ }^{a}$ & .11 & イス ${ }^{a}$ & .13 \\
\hline & 汽車 & .08 & アイスホッケー b & .06 & 本 ${ }^{a}$ & .11 & マッチ & .11 \\
\hline & 人力車 & .06 & ボクシング & .06 & メガネ & .11 & カメラ & .11 \\
\hline & スケボー & .05 & ドッジボール & .06 & チケット & .10 & 水着 ${ }^{a}$ & .10 \\
\hline & 救急車 & .05 & 空手 & .05 & 洗面用具 b & .10 & 机 & .10 \\
\hline & 馬車 & .05 & フィギュアスケート & .05 & 帽子 a & .08 & 方位磁石 a & .10 \\
\hline & ロケット & .05 & クリケット & .05 & クレジットカード a & .08 & 花火 b & .10 \\
\hline
\end{tabular}

注）1つのカテゴリーラベルにつき 63 名に事例の生成を求めた。生成率は 63 名のうち, 当該項目を生成した人数の比率である。 8 つのカテゴリーラベルについて生成を行った。付録ではその内の 4 つについて示している。

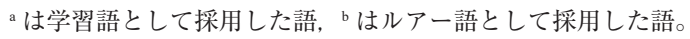

